SCJR 12, no. 1 (2017): 1-8

\title{
Rethinking the Notion of Universality in Judaism and its Implications
}

\author{
RUTH SANDBERG \\ rsandberg@gratz.edu \\ Gratz College, Melrose Park, PA 19027
}

This article was generated from the February 2016 Saint Joseph's University "Consultation on the Newest Statements about the Christian-Jewish Relationship."

\section{Introduction: Christ the Universal Mediator in "Gifts and Calling"}

The document published in December 2015 by the Vatican Commission for Religious Relations with the Jews, “"The Gifts and the Calling of God Are Irrevocable': A Reflection on Theological Questions Pertaining to Catholic-Jewish Relations on the Occasion of the 50th Anniversary of Nostra Aetate (No. 4)" (hereafter, G\&C), struggles to balance the notion of Christian "universality" with God's enduring covenant with the Jews. For instance, in the Preface, it is stated that the document will address "the relationship between the universality of salvation in Jesus Christ and the affirmation that the covenant of God with Israel has never been revoked." In $§ 25$, it is stated:

That his will for salvation is universally directed is testified by the Scriptures (cf. e.g. Gen 12:1-3; Is 2:2-5; 1 Tim 2:4). Therefore there are not two paths to salvation according to the expression "Jews hold to the Torah, Christians hold to Christ". Christian faith proclaims that Christ's work of salvation is universal and involves all mankind. God's word is one single and undivided reality which takes concrete form in each respective historical context. (Cf. §33.)

An entire section of the document, section 5, is titled "The universality of salvation in Jesus Christ and God's unrevoked covenant with Israel." It explicitly repeats that Christ's saving work impacts all humanity and cannot be seen to exclude Jews:

\footnotetext{
${ }^{1}$ All quotations from "The Gifts and the Calling of God Are Irrevocable: A Reflection on Theological Questions Pertaining to Catholic-Jewish Relations on the Occasion of the 50th Anniversary of Nostra Aetate (No. 4)," are taken from the text presented on the web site of the Council of Centers on Jewish-Christian Relations, http://www.ccjr.us/dialogika-resources/documents-and-statements/romancatholic/vatican-curia/1357-crrj-2015dec10.
} 
"[T] he Church and Judaism cannot be represented as "two parallel ways to salvation,' but that the Church must "witness to Christ as the Redeemer for all" (No. I, 7). The Christian faith confesses that God wants to lead all people to salvation, that Jesus Christ is the universal mediator of salvation, and that there is no 'other name under heaven given to the human race by which we are to be saved' (Acts 4:12). [\$35]....There cannot be two ways of salvation, therefore, since Christ is also the Redeemer of the Jews in addition to the Gentiles [§37].

The theme of Christian universality is also prominent in Section 6, dealing with the Church's mandate to evangelize. See especially $\S \S 40,42$, and 43.

It is clear from even a cursory reading of these passages that the notion of Christian universality is difficult to harmonize with the belief that the divine covenant with Israel exists independently outside of Christianity and is eternal and unbroken. Thus, "Another focus for Catholics must continue to be the highly complex theological question of how Christian belief in the universal salvific significance of Jesus Christ can be combined in a coherent way with the equally clear statement of faith in the never-revoked covenant of God with Israel” (\$37). In these passages, Christian universality is essentially defined as "universal" salvation exclusively through Jesus Christ and "involv[ing] all mankind." Furthermore, the new covenant made the Abrahamic covenant "universal" for all peoples, and Israel without the Church would "remain too particularist" and might not be able "to grasp the universality of its experience of God" (§33). God's revelation in Christ "has become totally manifest as the God of all peoples," since Jesus Christ is the "universal mediator of salvation" (§35). Since there can be only one way to salvation and not two, "Christ is also the Redeemer of the Jews in addition to the Gentiles" (\$37).

Although institutionalized missionizing to Jews is rejected, Christians should still confess and proclaim "the historical realization of God's universal will for salvation in Christ Jesus; (\$42)" and that Jews and Christians are seen as the "people of God of Jews and Gentiles, united in Christ" (\$43).

While the Jews remain in God's favor through an eternal covenant, the implication of this understanding of universality is that it is ultimately about God leading "all people to salvation through Jesus Christ as the "universal mediator of salvation"” (\$35). Therefore, Jews are part of the universality of the Church, but they have not yet achieved the ultimate goal of this universality, which is to find salvation in Christ.

From a Jewish perspective, this particular notion of universality may appear ungenerous, patronizing, and even offensive, and appears to have elements of triumphalism and supersessionism. However, if we trace the historical development of the idea of "universality," we see that the Christian triumphalist version of universality may actually have its roots in Judaism.

\section{Monotheism and Universality}


Some scholars believe that it is possible to interpret early Israelite monotheism itself as containing the seeds of triumphalism and supersessionism. For instance, nowhere does the Hebrew Bible acknowledge that any other religious system is equally legitimate to Israelite monotheism or shares in spreading the knowledge of the one true God. The practices of the other nations are viewed as idolatrous, polytheistic, immoral, and misguided, as seen in the following selection of verses: "When you enter the land which the Lord your God is giving you, you shall not learn to imitate the abhorrent practices of those nations" (Deut. 18:9); "They imitated the nations that were about them, which the Lord had forbidden them to emulate. They rejected all the commandments of the Lord their God; they made molten idols for themselves...." (2 Kings 17:15-16); "All the gods of the peoples are mere idols" (Psalm 96:5).

Furthermore, the covenant between God and Israel can be seen as exclusive to Israel and exclusionary of other nations. As Hava Tirosh-Samuelson notes: "Some voices in the Bible view the covenant with God exclusively, emphasizing the particularistic dimension of covenantal relations...." Louis Jacobs also acknowledges that "some Jews have spoken as if God's chief, if not total, interest, so to speak, is with 'His' people.", Jon Levenson notes that the outsider "may be condemned as an offense to the universal lord whom he does not acknowledge... or he may be regarded as a person of diminished dignity whose true worth can be realized only by his electing to join the favored sub-group....the particular religious tradition will tend to identify itself with humanness itself, and to imply the subhumanity of outsiders...." This statement concerning biblical Israel and outsiders could be re-read as the attitude of the triumphalist Church toward the Jews.

Even those texts which may reflect pre-monotheistic monolatry (i.e., worshiping one God while acknowledging that other gods exist) does little more than accept these other gods' existence; these divinities are never praised or attributed with the power and ethical standards associated with the God of Israel. For instance, Exodus 15:11 states: "Who is like You, O Lord, among the celestials," and Exodus 20:3 declares: "You shall have no other gods besides Me." Similarly, in the declaration that became the Sh'ma, Deuteronomy 6:4 commands, "Hear, O Israel! The Lord is our God, the Lord alone." Jeffrey Tigay notes that this "is not a declaration of monotheism....though other peoples worship various beings and things they consider divine, Israel is to recognize YHVH alone."5 Such verses may imply that other gods exist but no value is attached to them. Another biblical scholar states that "the question was not whether there is only one elohim, but

\footnotetext{
${ }^{2}$ Hava Tirosh-Samuelson, “A Jewish Perspective on Religious Pluralism,” Macalester International 8 (2000): 77.

${ }^{3}$ Louis Jacobs, A Concise Companion to the Jewish Religion (New York: Oxford University Press, 1999), 570.

${ }^{4}$ Jon D. Levenson, "The Universal Horizon of Biblical Particularism," in Ethnicity and the Bible, Dana de Priest, ed., (Leiden: Brill Academic Publishers, 2002), 144.

${ }^{5}$ Jeffrey Tigay, The Jewish Publication Society Commentary to Deuteronomy (Philadelphia: Jewish Publication Society, 1996), 76.
} 
whether there is any elohim like Yahweh." ${ }^{, 6}$ Even in the case of Israelite monolatry, the God of Israel is still incomparable and supreme, which could also be interpreted as a triumphalist viewpoint.

Furthermore, Israelite monotheism can be seen as triumphalist in defining that the ultimate destiny of the other nations will inevitably be to acknowledge the singularity of the God of Israel. Psalm 67:4 looks forward to the time when "all peoples will praise You." Similarly does Psalm 86:9 proclaim: "All the nations You have made will come to bow down before You, O Lord, and they will pay honor to Your name." While the other nations do not presently accept the one God of Israel, in the glorious future they will come to realize the singular truth of Israelite monotheism. Thus, the concept of "universality" in the Tanakh can be defined as the belief that human history will culminate with all the nations becoming followers of its particular monotheistic teaching. Hebrew universality also implies that becoming a monotheist as defined by the Tanakh is superior to remaining a polytheist (or a Christian), since only Israelite monotheism is viewed as a universal ideal. This may have been the foundation for the later notion of Christian universality, in which the ideal is for salvation to be extended to all the nations through Christ.

Jews who object to the Christian notion of universality should keep in mind that Israelite monotheism holds a similar belief that the entire world is destined to become followers of Israel's God. In essence, both Jewish and Christian monotheism can be seen as triumphalist and superseding all other non-monotheistic beliefs. Nicholas de Lange defines this triumphalist universality in the following manner: "There is only one God for all humanity, and even if they do not recognize him now they will at a future time." Jacob Neusner also notes that "the logic of monotheism...yields little basis for tolerating other religions." 8 David Horell insists that in the Christian concept of triumphalist universality, "everyone can live peacefully and tolerantly together, as long as it is under the umbrella of the system of values and practices that we determine and impose." ${ }^{9}$ Jon Levenson suggests that "another understanding of 'universalism' may teach us that in some future consummation, human variety will disappear altogether or submit permanently to an all-inclusive structure., ${ }^{, 10}$ Pope Francis recently commented on both Islam and Christianity: "It is true that the idea of conquest is inherent in the soul of Islam. However, it is also possible to interpret the objective in Matthew's Gos-

\footnotetext{
${ }^{6}$ John McKenzie, "Aspects of Old Testament Thought," in Raymond E. Brown, Joseph A. Fitzmyer, and Roland E. Murphy, eds., The New Jerome Biblical Commentary (Upper Saddle River, NJ: Prentice Hall, 1990), 1287.

${ }^{7}$ Nicholas de Lange, An Introduction to Judaism (Cambridge, UK: Cambridge University Press, 2010), 32 .

${ }^{8}$ Jacob Neusner and Bruce Chilton, eds., Religious Tolerance in World Religions (West Conshohocken: Templeton Press, 2008), 61.

${ }^{9}$ David Horell, "The West's Christian World View is a Hindrance to Peaceful Co-existence," at https://theconversation.com/the-wests-christian-world-view-is-a-hindrance-to-peaceful-co-existence$\underline{58350 .}$

${ }^{10}$ Levenson, op. cit., 145.
} 
pel, where Jesus sends his disciples to all nations, in terms of the same idea of conquest."11

\section{Inclusive Universality}

On the other hand, there is another perspective in Israelite monotheism that exhibits aspects of what I would term an "inclusive universality." Inclusive universality is more open and accepting of the legitimacy of others who relate to the divine in ways that differ from Israel. Louis Jacobs acknowledges that Judaism maintains a delicate balance between universalism and particularism in the Israelite covenant, but insists that "in the very affirmation of God's choice of Israel the universalistic idea is implied....a universal God, in the sense of one who has equal concern for all peoples on earth, does not choose a particular people to achieve part of His purpose in creating the nations of the world, unless it be held that He has a special purpose for each of the peoples of the world."12 Nicolas de Lange notes that the fact "that the Bible begins with the creation of the world and humanity instead of the beginnings of the people can be used as an illustration of the centrality of universalism in Judaism....The Bible is full of reminders to the Jews that their God is the God of all the nations." 13 Jon Levenson also focuses on the universality of creation:

The placement of the story of cosmic creation by God (elohim) at the beginning of the entire Bible (Gen. 1:1-2:3) establishes a universal horizon for the particular story of Israel...men and women, created together, exist on undifferentiated dry land. No spot on earth can claim the prestigious status of primordiality....All people are created equally in the divine image. The creation stories serve as a powerful warrant for a Jewish doctrine of human solidarity....

In fact, Levenson also insists that the creation story "presents humankind as primordially monotheistic," 15 but their form of monotheism is non-Israelite. What this means for Israel is that they are not the first people to be monotheists, nor do they hold the only legitimate conception of monotheism, but they are the people chosen to bring humanity, all made in the image of God, back to the original preIsraelite monotheism that existed before humanity began to backslide into idolatry.

Yet if a return to the original universal monotheism is the goal of all of humanity, this could nevertheless imply that all nations, including Israel, must give up their uniqueness and separate identity and become indistinguishable. However,

\footnotetext{
11 "Islam and Christianity Both Have 'Idea of Conquest,' Says Pope Francis," http://www.sltrib.com/home/3900882-155/islam-and-christianity-both-have-an.

${ }^{12}$ Jacobs, op. cit.

13 de Lange, op. cit., 34.

${ }^{14}$ Levenson, op. cit., 144-145.

15 Ibid., 148
} 
some scholars insist that the Tanakh sees each nation as retaining its uniqueness upon becoming monotheists once again at the end of time. Levenson states that "Israel does not disappear into an undifferentiated humanity. Rather, it and the nations survive, only now centered upon the service of $\mathrm{YHVH}$, the universal creator, king, and redeemer...." In fact, Levenson sees the concept of an undifferentiated humanity at the end of time as destructive to the very nature and uniqueness of both Judaism and Christianity. ${ }^{16}$ Michael Walzer, in analyzing the universality at the end of time in Isaiah 2, focuses on verse 4: "Thus He will judge among the nations and arbitrate for the many peoples." This verse assumes that there will be differences and even disputes among the various cultures that will survive into the world to come. In fact, they will still have conflicts because of their dissimilarities and various ways of understanding God, but they will be resolved immediately by one divine judge. ${ }^{17}$

\section{Rabbinic Views}

When turning to classical rabbinic Judaism, both triumphalist and inclusive universality can be found as well. Alan Segal points out that some Jews "refused to allow the possibility that some Gentiles could be saved as Gentiles, who even would not accept any Gentiles into the Israelite faith." ${ }^{18}$ Rabbi Akiva is associated with a ban against Gentiles studying the Torah at all. ${ }^{19}$ In BT Sanhedrin 105a, Rabbi Eliezer insists that Gentiles will not be permitted to enter the world to come, making the culmination of human history exclusively for Jews. Rabbinic Judaism, and the Roman society in which it developed, may have been "convinced that heaven had selected it to rule the world. Neither could accept with equanimity any challenge to its claims." ${ }^{, 20}$ Ironically, the rabbis may have absorbed the triumphalist universality of Rome into their own thinking.

A somewhat intermediate position between triumphalist and inclusive universality can be found in rabbinic sources which insist that the Torah is available to all people. The fact that rabbinic Judaism developed a formal process by which a non-Jew could convert to Judaism is one aspect of rabbinic universality. One does not have to be born within Israel but can join Israel through conversion, and this emphasizes that the Torah was not meant exclusively for native-born Jews alone. In fact, the Mekilta de R. Ishmael states that the Torah was given "in the wilderness publicly and openly, in a place that is free for all; everyone wishing to accept it could come and accept it." ${ }^{21}$ Marc Hirshman notes that "Torah is availa-

\footnotetext{
${ }^{16}$ Ibid, 167-168.

${ }^{17}$ Michael Walzer, "Universalism and Jewish Values," https://www.carnegiecouncil.org/publications/archive/morgenthau/114.html.

${ }^{18}$ Alan Segal, "Universalism in Judaism and Christianity," in Paul in His Hellenistic Context," Troels Engberg-Pedersen, ed.(Edinburgh: T \& T Clark, 1994), 4.

${ }^{19}$ See Marc Hirshman, "Rabbinic Universalism in the Second and Third Centuries," Harvard Theological Review 93:2 (2000):115.

${ }^{20}$ Ibid., 113.

${ }^{21}$ Jacob Lauterbach, Mekilta de Rabbi Ishmael Bahodesh 1(Philadelphia: The Jewish Publication Society, 2004), 198.
} 
ble to all those who come into the world. It remains in place, available for anyone to take it. Torah is the litmus test for all humanity, not just the Jews." 22 In fact, the Gentile who observes Torah without converting still receives merit for it and "will enter the gates of paradise." 23 Hirshman labels this welcoming attitude to Gentiles as rabbinic universalism, but while it is admirable, it is far from inclusive universality. The ultimate "litmus test" for worthiness is still the Torah, which, although intended for the world, has become the possession of Israel. This notion that the whole world needs to "come to Torah" to be meritorious in the eyes of God is not that different from the Christian triumphalist view that all must "come to Jesus" in order to have salvation.

Yet a more developed sense of inclusive universality also appears in rabbinic sources. The doctrine of the Noahide commandments, the rabbinic teaching that God made a covenant with all of humanity consisting of seven commandments that preceded the revelation at Sinai, has an element of inclusive universality within it. The significance of this doctrine lies in its insistence that all human beings can participate in a covenantal relationship with God without the necessity of being a member of Israel and can attain the virtues of morality and righteousness without full Torah observance.

Another way in which inclusive universality appears in rabbinic literature involves the resident sojourner. The rabbinic community welcomed Gentile sojourners into its midst, with the proviso that they participate in observing some of the Torah commandments beyond the Noahide laws, such as circumcision and the purity and food laws. These Gentiles living among Jews were not required to convert to Judaism, only to acculturate to certain communal observances. Thus, whether through following the Noahide laws or becoming resident sojourners, the rabbis recognized that "righteous Gentiles existed and that they were part of God's plan without conversion." 24

Three final examples demonstrate aspects of inclusive universality in rabbinic Judaism. Talmud Yerushalmi Avodah Zarah 2:1 expresses the view that "the ultimate stage of humanity will comprise both Judaism and Noahism"; rather than requiring Gentiles to move beyond the Noahide laws to full Torah observance and conversion, they are allowed to partake of humanity's ultimate culmination in their current status. ${ }^{25}$ In a rebuttal against Rabbi Eliezer barring Gentiles from the world to come, Rabbi Joshua insists that Gentiles "who have not forgotten God" and are thus righteous will be accepted into the world to come (BT Sanhedrin 105a). As long as the Gentiles have an awareness of the divine within the created world, they are to be welcomed into the world to come. Lastly, Avot de R. Natan 35 ends with a statement by Rabban Shimon ben Gamliel: "In the future Jerusalem will be the gathering place of all the nations and all the kingdoms, as it is said, 'All the nations shall be gathered unto it, to the name of the Lord, to Jerusalem' (Jer. 3:17)." If we apply inclusive universality to this text, it teaches that the

\footnotetext{
${ }^{22}$ Hirshman, op. cit., 107.

${ }^{23}$ Ibid., p. 108.

${ }^{24}$ Segal, op. cit., 29.

${ }^{25}$ See Yosef Green, “Universalism and/or Particularism," Jewish Bible Quarterly 30:1 (2002):6.
} 
nations can exist side by side with Israel in a renewed creation that allows for the distinctive variety of humanity united in their diverse ways of recognizing the divine. While admittedly the setting is Jerusalem, the very symbol of Judaism, the nations are welcome as they are.

\section{Conclusion}

Such sentiments reveal that it is possible for Judaism to accept the notion of a redeemed world in which all people are equally worthy just as they are and however they express their connection to the divine. Let me also suggest that the term "universality" in "Gifts and Calling" might be redefined in the future as inclusive universality, which would allow Jews and other non-Christians to thrive in a world that is redeemed by each community finding its own unique connection to the divine. If Judaism and Christianity could encourage all people in their own way to come to an understanding of the transcendent, that might also be seen as a fulfillment of Jesus's command to "make disciples of all the nations" in Matthew 28:19. If Judaism rejects Christian triumphalist universality, which insists that the only path to salvation for humanity is through Christ, then Judaism must also reject its own triumphalist universality in which the only path to salvation is through the Torah and conversion to Judaism.

The goal is not for all humanity to be united in an undifferentiated homogenization without ethnic or religious differences. Inclusive universality allows for an optimistic view of a future in which all are welcome to join in each other's traditions, but which also sees each distinct people or community as inherently worthy in its unique conception of the divine. Judaism and Christianity still struggle with defining what their role will be in the culmination of human history, but perhaps by reinterpreting the meaning of universality, we will move closer to that end. 